\title{
IMPACT OF FATWA UPON BANK INTEREST BAN ON THE DEVELOPMENT OF ISLAMIC BANKING IN INDONESIA
}

\author{
Diana Ambarwati \\ Faculty of Islamic Economics and Business, Metro State Islamic Institute \\ J. Ki Hajar Dewantara No.15A, Iringmulyo, Kec. Metro Tim., Kota Metro, Lampung 34112 \\ Email: diana.ambarwati29@gmail.com
}

\begin{abstract}
The purpose of this article is to describe the impact of bank interest ban fatwa on the development of Islamic Banks in Indonesia. Fatwa of the Indonesian Ulama Council number 1 of 2004 is the basis for various parties to contribute to realizing competitive Islamic banking. This fatwa has encouraged the Government to issue various rules in the form of laws and government regulations related to banking. The issuance of this rule is a serious proof of the government's commitment to provide more space for the development of Islamic banking in Indonesia, in addition to being a proof of appreciation for the issuance of bank interest ban fatwa by the Indonesian Ulema Council. In addition, the bank's fatwa on the ban on bungan has encouraged the role of the community to contribute real to the development of Islamic banking. The emergence of the Association of Islamic Economists (IAEI), sharia economic community (MES), the National Committee of Islamic finance which is now renamed to the National Committee of Islamic Economics and Finance (KNEKS) is a concrete evidence of community contribution to socialize and strengthen Islamic banking.
\end{abstract}

Keywords: Fatwa; Bank Interest; Islamic Banking; Indonesia

\begin{abstract}
Abstrak: Tujuan dari artikel ini untuk mendiskripsikan dampak fatwa keharaman bunga bank terhadap perkembangan Bank Syariah di Indonesia. Fatwa Majelis Ulama Indonesia nomor 1 tahun 2004 merupakan dasar bagi berbagai pihak untuk turut berkontribusi mewujudkan perbankan syariah yang berdaya saing. Fatwa ini telah mendorong Pemerintah untuk menerbitkan berbagai aturan berupa Undang-Undang dan Peraturan Pemerintah terkait perbankan. Terbitnya aturan ini merupakan bukti serius komitmen pemerintah untuk memberikan ruang lebih bagi pengembangan perbankan syariah di Indonesia, di samping sebagai bukti apresiasi atas terbitnya fatwa keharamanan bunga bank oleh Majelis Ulama Indonesia. Selain itu, fatwa keharaman bunga bank tersebut telah mendorong peran masyarakat untuk berkontribusi nyata bagi pengembangan perbankan syariah. Munculnya Ikatan Ahli Ekonomi Islam (IAEI), Masyarakat Ekonomi Syariah (MES), Komite Nasional Keuangan Syariah yang sekarang berubah nama menjadi Komite Nasional Ekonomi dan Keuangan Syariah (KNEKS) merupakan bukti kongkrit kontribusi masyarakat untuk mensosialisasikan dan menguatkan perbankan syariah.
\end{abstract}

Kata kunci: Fatwa; Bunga Bank; Perbankan Syariah; Indonesia 


\section{Introduction}

Islamic economics has broad dimensions, both macro and micro scales, both social and institutional. Banking and insurance is one of the most prominent dimensions of the sharia economy in society. These three institutions are financial institutions that have direct contact with the public. However, institutionally, these two institutions did not exist at the time of the Prophet. Thus, the practice of banking and insurance institutions is included in the area of ijtihadi. So it is natural that there are differences of opinion and fatwas from both individual scholars and organizational groups.

But first, we will discuss what a fatwa is. In language Fatwa is an answer to an event and or incident. Meanwhile, according to the term that a fatwa explains sharia law on a problem as an answer submitted by an individual or group (collectively) to a mufti. ${ }^{1}$

In al-kasysyaf, Zamakhsyari defines fatwa comes from the word al-fatad which means youth, which can be interpreted as a straight and right path. ${ }^{2}$ The term fatwa according to al-Raqib al-Isfahani can be found in the Qur'an with different terms, even though it actually has the same meaning, namely the answer to legal questions that were often asked by the Prophet at that time. ${ }^{3}$ Some literature explains that fatwas are answers or explanations from scholars regarding religious issues and apply to the public. ${ }^{4}$

Fatwa is an opinion expressed by Islamic

1 Yusuf Qardhawi, Fatwa Antara Ketelitian Dan Kecerobohan (Jakarta: Gema Insani Press, 1997), p.5.

2 Rohadi Abdul Fatah, Analisis Fatwa Keagamaan Dalam Fiqih Islam (Jakarta: Bumi aksara, 2006), p.7.

3 Muhammad Fuad Abd Al-Baqi, Al-Mujam AlMufahras Li Al-Fazh Alquran Al-Karîm (alQahirah : Dar al-Hadis, 2007), p.623.

4 KBBI, "Kamus Besar Bahasa Indonesia (KBBI) Kamus Versi Online/Daring," Kemendikbud, 2020; Qardhawi, Fatwa Antara Ketelitian Dan Kecerobohan.; Pedoman Penetapan Fatwa Majelis Ulama Indonesia, Nomor: U-596/MUI/X/1997 jurists (fuqaha) about the legal position of a new problem that arises in the community. When a new problem arises for which there is no explicit (firm) legal provision, both in the Qur'an, Sunnah and ijma' as well as the opinions of previous fuqaha, the fatwa is one of the normative institutions that is competent to answer or determine the legal position of the problem. ${ }^{5}$

The fatwa consists of three elements: a question (su'âl istiftâ), a fatwa (mufti), and an answer (jawâb). A person (mustaft) poses a question to a mufti, who then provides the answer. When the question is compiled or written on a piece of paper, then the paper is then known as ruq'ah al-istiftá $\hat{a}^{\prime}$ and kitâb al-istiftâ. ${ }^{6}$

Regarding the question (su'âl istiftâ), Atho Mudzhar stated that in the current context the fatwa institution no longer waits for questions from mustafti first, but must be more aggressive in reading the problems that arise in the community. In this case, the problem becomes mustafti as a problem that must be solved and the answer found. ${ }^{7}$

\section{Fatwas on the Haram of Riba in Indonesia}

The practice of banking actually happened at the time of the Prophet and his Companions. Institutions such as the Baitul Maal at that time had performed several banking tasks, namely accepting depository funds, lending funds to customers either by means of mudharabah, musyarakah, muzara'ah and masaqqh contracts,

${ }^{5}$ M Erfan Riadi, "Kedudukan Fatwa Ditinjau Dari Hukum Islam Dan Hukum Positif (Analisis Yuridis Normatif)," ULUMUDDIN, 2010.

${ }^{6}$ Wael B. Hallaq, "From Fatwâs to Furü: Growth and Change in Islamic Substantive Law," Islamic Law and Society, 1994, https://doi.org/10.1163/156851994X00147.

${ }^{7}$ M. Atho Mudzhar, "Revitalisasi Maqasid Al-Shari'ah Dalam Pengembangan Ekonomi Syariah Di Indonesia (Studi Kasus Atas Fatwa-Fatwa DSN-MUI Tahun 20002006)," JURNAL INDO-ISLAMIKA, 2014, https://doi. org/10.15408/idi.v4i1.1558. 
as well as providing fund transfer services. However, the term banking or bank was not known at that time. Banking functions at the time of the Prophet had been carried out by individuals and not just one task.

Furthermore, in its development, during the Abbasid caliphate, several tasks and functions as described above were carried out by only one person. After this banking practice continued to develop, various currencies and currencies with gold and silver content emerged. Bank players had an active role in the economy during the Abbasid caliphate, and became familiar and popular during the reign of Caliph al-Muqtadir (908-932). At this time each wazir (minister) had his own banker. For example: Ibn Furat appointed Harun Ibn Imran and Josep Ibn Wahab as his bankers. The practice of banking is becoming more widespread with the existence of checks (saq) as a means of payment. Saezfudaulah al-Hamdani was the first person to issue and issue checks for the purpose of inter-state payments, commonly known as clearing. Payment of trade between countries such as Baghdad, with Spain (Alepo). ${ }^{8}$

Thus, it can be seen that banking practices have existed before but have not yet been institutionalized. It's just that, when banking interest rates are associated with the term usury. ${ }^{9}$ In response to this, the scholars experienced differences of opinion, some were prohibited on the grounds of an additional element (alziyâdah), but some scholars argued that it was permissible on the grounds that the practice of bank interest was considered not to be

\footnotetext{
${ }^{8}$ Sudin Haron, Islamic Banking: Rules and Regulations (Petaling Jaya: Pelanduk Publications, 1997); Zamir Iqbal and Abbas Mirakhor, "Progress and Challenges of Islamic Banking," Thunderbird International Business Review, 1999, https://doi.org/10.1002/tie.4270410406.

${ }^{9}$ Faidlullah, Fath Al-Rahmân Li Thâlib Âyât Al-Qur'an (Semarang: CV. Diponegoro, n.d.), h.171; Hans Wehr, A Dictionary of Modern Written Arabic (London: George Allen and Unwin Ltd, 1971), h.324; Ibn Al-Arabî, Ahkâm Al-Qurân, Juz 1 (Mesir: Isa al-Halaby, 1957),p.321.
}

doubled (ad'afan mudho'afah) and that there was no element of persecution. ${ }^{10}$

This difference of opinion then raises the supporting argument. The first group argues that usury nasi'ah or what is known as usury jahiliyyah is unlawful as regulated by definite texts. While the reason for the prohibition of usury fadhl, is because it will be the cause and path to the practice of usury nasi' $a h$ and usury jahiliyah. ${ }^{11}$ The group of exegetes who agree with this group is al-Jashshash, ${ }^{12}$ alQurthubi, al-Syaukani, and Sayyid Qutb. These commentators are of the opinion that the sentence adl'afan mudhâ'afatan is not a limitation or requirement for the prohibition of the practice of usury. The term adl'âfan mudhâ'afatan is a description of the practice of usury carried out by pre-Islamic Arab society. Then confirmation of this view emerged from later Islamic thinkers such as Abu al-A'la alMaududi, and Nejatullah al-Shiddiqie. In their view, what is called usury is any addition to the principal of the loan, whether it is a small amount or a large amount.

In other groups, there are also views that are different from the first group. This group is of the opinion that what is unlawful is usury nasiah or usury jahiliyyah, while the type of usury fadhl is not unlawful. This is because the sentence adl'afan mudha'afatan contained in the letter Ali Imran verse 130 and la

10 Rahmat Firdaus, "Perbedaan Pandangan Fuqaha Ihwal Bunga Bank Dan Riba," EKONOMIKA SYARIAH : Journal of Economic Studies, 2019, https:// doi.org/10.30983/es.v3i2.2150; Singodimedjo, R.H. Kasman, Bunga Itu Bukan Bank Dan Bank Itu Tidak Haram (Jakarta: Pustaka Antara, 1972), p.17.

${ }^{11}$ Rizal Bin Jami’an, "Ijtihad Jama’i Nahdatul Ulama (NU) dan Ijtihad Qiyasi Muhammadiyah tentang Bunga Bank dalam Praktik Perbankan," Jurnal Hukum Respublica, 2018, https://doi.org/10.31849/respublica.v16i1.1424; Muhammad Ali bin Muhammad Al-Syaukani, Fath AlQadîr Bayna Fann Al-Riwâyah Wa Al-Dirâyah Min Ilm Al-Tafsîr, Juz 1 (Beirut: Dâr al-Fikr, n.d.), p.294.

${ }^{12}$ Al-Jashshash, Ahkam Al-Qur'an, Juz II (Beirut: Dâr al-Kutub al-'Ilmiyyah, n.d.), p.37. 
tadhlimuna wa la tudzlmuna in the letter alBaqarah verse 279 is a limitation and condition for the prohibition of usury. So if there is an addition to the loan but it is not doubled and there is no element of persecution, the law is not prohibited. This view of the mufassirin is expressed by al-Maraghi, al-Tabari, and Rashid Rida.

Meanwhile, the Indonesian cleric, Quraish Shihab, argues that the term usury means "excess". However, if the meaning of this language is the benchmark, then the opinion of the first group becomes true. When later the opinion emerged that "selling and buying is the same as usury" Allah firmly replied that "God has justified buying and selling and forbids usury". This verse is an affirmation without mentioning other arguments explicitly. So that it can be ascertained that buying and selling is halal and the prohibition of usury. ${ }^{13}$

Back to the discussion of bank interest which was associated with the practice of usury in the past. Of course, this discourse will still be an interesting debate in Islamic studies. On the one hand there is the law of usury which is still debatable, but on the other hand there is the practice of banking interest which has several elements similar to the practice of usury in the past. Although in practice bank interest at this time is understood as a reward for loan services provided. ${ }^{14}$

Likewise, Ulama in Indonesia also have different views about the law of bank interest whether it is the same as usury or not. For example, Nahdhatul Ulama (NU), within this organization there are also differences of opinion, some are of the opinion that bank interest is the same as usury, but others are of

${ }^{13}$ M. Quraish Shihab, Wawasan Al-Qur"an; Tafsir Maudhu"i Atas Berbagai Persoalan Umat (Bandung: Penerbit Mizan, 1998), p. 413.

${ }^{14}$ Edy Suandi Hamid, "Akar Krisis Ekonomi Global Dan Dampaknya Terhadap Indonesia," La_Riba, 2009, https://doi.org/10.20885/lariba.vol3.iss2.art1. the same opinion and some are of the opinion that the practice of bank interest is permissible or syubhat. However, this difference of opinion does not then make this organization insist on these differences. In 1992, at the Bahtsul Masail National Deliberation in Lampung, $\mathrm{NU}$ issued a recommendation to establish an NU Islamic bank with an interest-free system.

Likewise, Muhammadiyah, a study by Lajnah Tarjih in Sidoarjo in 1968, discussed that bank interest provided by state-owned financial institutions is legally mutasyabihat. The recommendation is for PP Muhammadiyah to develop a concept of a financial institution that is in accordance with Islamic law.

In line with Muhammadiyah, the Indonesian Ulema Council clearly views that bank interest is unlawful because it is not in accordance with sharia. This is stated in the MUI fatwa number 1 of 2004 . There are several considerations that are used as the basis for the prohibition of bank interest (interest/fa'idah) by the MUI, namely the opinion of fiqh scholars that the interest charged in loan transactions (debts and receivables, al-qard wa iqtiradh) has met the criteria for usury which is forbidden by Allah SWT. And rests his opinion on the following opinion:

First, the opinion of Imam Nawawi in almajmu' states that the scholars of the Shafi' school have different opinions about the prohibition of usury, and are divided into two major opinions. First, the prohibition of usury is global (mujmal) as explained by the sunnah. Every Sunnah that explains the prohibition of usury is an explanation of the generality and globality (mujmal) of the Qur'an. This applies to both usury nasi'ah and usury naqd. Second, the law on the prohibition of usury in the Qur'an by this view only covers usury nasi'ah as was the custom of the pre-Islamic Arab community, which asked for additional loans to be multiplied when the borrower was unable to repay the loan after it was due. This 
practice is what Allah then said: "... do not eat usury doubled...". Which is strengthened by the sunnah which discusses usury in the practice of currency exchange (naqd). ${ }^{15}$

Second, the opinion of Ibn al-'Araby in the Ahkam al-Qur'an, argues that in language usury means additional or excess. While what is meant by usury in the Qur'an is any addition or excess that has no reward. ${ }^{16}$

Third, Al-Aini in Umdah al-Qari' has the same opinion when interpreting usury in language, while in Islamic law the meaning of usury is every addition and excess of the main assets used without or without trading and buying and selling contracts.

Fourth, Al-Sarakhsyi in al-Mabsuth, argues that usury is an excess (additional) without the required compensation in buying and selling. Fifth, the opinion of Yusuf al-Qardhawy in Fawa'id al-Bunuk which states that bank interest is usury which is forbidden. Bank interest is haram, haram, haram. Riba or bank interest is usury nasi'ah, whether the interest is low or double. (That's) because the main activity of the bank is to provide debt (loans) and receive debts (loans). The danger (madharat) of usury is fully realized (in full) in bank interest. Bank interest is haraam, haram, haram, like usury. ${ }^{17}$

In addition to relying on some of the opinions mentioned above, the decision of the Indonesian Ulema Council regarding the prohibition of the practice of bank interest is also based on several provisions of various International Ulema Forums, such as Majma'ul Bubuts al-Islamiyyah which was held in May 1965 at al-Azhar Egypt, Majma' al-Fiqh al-Islamy OIC countries which was held from 22 to 28 December 1985 in Jeddah, Majma' Figh Rabithah al-'Alam al-Islamy, which was held from 12 to 19 Rajab $1406 \mathrm{H}$

\footnotetext{
${ }^{15}$ Imam Nawawi, Al-Majmu Syarh Al-Muhadzadzah, tt: (Dar al-Fikr, n.d.), juz.9, p. 391.

${ }^{16}$ Al-Arabî, Ahkâm Al-Qurân, Juz 1.

17 Yusuf Al Qardhawi, "Halal Dan Haram Dalam Islam,” Pustaka Nasional Pte Ltd, 2001.
}

in Makkah, Decision of Dar al-Itfa, Kingdom of Saudi Arabia, in 1979, and Decision of the Supreme Shariah Court of Pakistan of December 22, 1999.

This is the fatwa regarding the prohibition of bank interest by the Indonesian Ulema Council. However, according to Maruf Amin as chairman of the Indonesian Ulema Council, he explained that the entire territory of Indonesia was still an emergency, so he also emphasized that this fatwa was not binding. ${ }^{18}$

\section{The Impact of the Fatwa on the Prohibition of Usury on the Development of Islamic Banking in Indonesia}

In the previous description it has been stated that socio-religious institutions agree on the prohibition of usury, although there are still differences of opinion regarding the law on bank interest that is practiced in Indonesia. However, all of these institutions agreed to create a financial system and/or financial institution in accordance with Islamic sharia.

The Fatwa of the Indonesian Ulema Council number 1 of 2004 has had a strong enough impact on the development of Islamic banking in Indonesia. Although it is not binding, this fatwa encourages many parties to play an active role in the realization of a strong superior Islamic banking. This form of active role, indicated by the government's support for the development process of Islamic banking is also increasingly evident. Previously, the government had issued a law as a form of appreciation for Islamic banks. For example, the establishment of the converting bank in 1991, which incidentally became a pioneer of Islamic banking in Indonesia, the government welcomed it by issuing Law no. 7 of 1992 concerning Banking, in which it discusses the profit-sharing banking

18 Maruf Amin's statement was written by Olivia Rosalia and Jhoni Akbar, MUI: Fatwa Haram Bank Interest is not binding in https:/www.liputan6.com/ news/ $\mathrm{read} / 68559 /$ mui-fatwa-haram-bunga-bank-tak-mengikat. 
system. In the law, article 13 paragraph (c) states that one of the efforts of Rural Banks (BPR) is to provide financing for customers based on the principle of profit sharing. As a follow-up to that article, the government then issued Government Regulation (PP) No. 72 of 1992 concerning banks based on the principle of profit sharing. ${ }^{19}$

The next step is the issuance of Law no. 10 of 1998 concerning amendments to Law No. 7 of 1992 concerning Banking, has provided even greater opportunities for the development of Islamic banking in Indonesia ${ }^{20}$ there is no exception for the permit to open a Sharia Branch Office (KCS) by conventional banks. In other words, commercial banks can carry out two business activities, both conventionally and based on sharia principles.

Not until here, seeing the development of Islamic banking which is getting better after the fatwa of usury by the MUI and several religious organizations, the government issued Law no. 21 of 2008 concerning Islamic Banking. This law is expected to be able to encourage the development of Islamic banking in Indonesia, whose market share is still less than 5\%. This law introduces several new legal terms and institutions, namely regarding the spin-off of the Sharia Business Unit from its parent institution. ${ }^{21}$

After the development of the government's role as a policy maker, let's look at the development of the quantity of Islamic

${ }^{19}$ Haryono Haryono and Raudya Pertiwi, "Regulasi Lembaga-Lembaga Fasilitator Sebagai Penentu Arah Kebijakan Operasional Bank Syariah,” Ad-Deenar: Jurnal Ekonomi Dan Bisnis Islam, 2020, https://doi.org/10.30868/ ad.v4i01.753.

${ }^{20}$ Nofinawati Nofinawati, "Perkembangan Perbankan Syariah di Indonesia," JURIS (Jurnal Ilmiah Syariah), 2016, https://doi.org/10.31958/juris.v14i2.305.

${ }^{21}$ M. Nur Rianto Al Arif, Ismawati Haribowo, and Ade Suherlan, "Spin-off Policy and Efficiency in the Indonesian Islamic Banking Industry," Banks and Bank Systems, 2018, https://doi.org/10.21511/bbs.13(1).2018.01. banking. As of 2019, OJK has released data on the number of Islamic banks in Indonesia, totaling 189 Islamic banks consisting of 14 (fourteen) Sharia Commercial Banks (BUS), 20 (twenty) Sharia Business Units (UUS), and 164 (one hundred and sixty four) Rajyat Syariah Credit Bank (BPRS) in Indonesia. ${ }^{22}$ However, the large quantity of Islamic banking does not necessarily make this Islamic banking strong. For this reason, scientific studies continue to be encouraged and produce recommendations to merge several Islamic banks. In February 2020, 3 (three) Islamic commercial banks merged into 1 (one) bank, namely the Indonesian Sharia Bank or BSI for short. The three banks are Bank Syariah Mandiri, BNI Syariah, and BRI Syariah. The spirit of accelerating the development of Islamic banks in Indonesia.

The establishment of Bank Syariah Indonesia is part of the Government's efforts and commitments in advancing the Islamic economy as a new pillar of national economic strength which in the long term will also encourage Indonesia to become one of the world's Islamic financial centers. Based on data on the development of Islamic banking from time to time, it shows that the government's commitment is getting better. This commitment was shown after the government received sharia legal certainty regarding bank interest and usury.

In addition to the active role of the government in encouraging the development of Islamic banking, the MUI Fatwa also encourages the role of the community to also contribute to developing Islamic banks. In the 2012 Islamic Economist Association's Anniversary event, Halim Alamsyah in the paper presented about the challenges of Islamic banking in Indonesia. ${ }^{23}$

${ }^{22}$ https://www.ojk.go.id/id/kanal/syariah/data-danstatistik/statistik-perbankan-syariah/Documents/Pages/ Statistik-Perbankan-Syariah

${ }^{23}$ Halim Alamsyah, "Perkembangan Dan Prospek Perbankan Syariah Indonesia: Tantangan Dalam Menyongsong MEA 2015," Milad Ke-8 Ikatan Ahli Ekonomi Islam (IAEI), 2012. 
The first challenge relates to the fulfillment of human resources, both in quantity and quality. The rapid development of Islamic banking does not have adequate human resources. For this reason, support from academics and related ministries is important, so that they are able to meet the needs of human resources who have adequate competency qualifications to contribute to developing Islamic banking. ${ }^{24}$

The second challenge is the innovation of developing competitive Islamic banking products and services based on the specific needs of the community. In this case, Islamic banks cannot just stick with standard products, and new product innovations are needed that are more attractive to the public. The third challenge is the continuity of outreach and education programs to the community. Until now, the socialization and education of sharia banking is supported by Bank Indonesia through the 'iB Campaign' program, either through public service advertisements, sharia expo, organizing workshops/seminars, etc.

\section{Conclusion}

Based on the description above, it can be concluded that the MUI fatwa number. 1 of 2004 concerning the prohibition of usury has had an impact on increasing many parties to take an active role in realizing banking that is free from the interest system. The development of Islamic banking in Indonesia has shown a good record in its development, both in terms of quantity and quality. There has been an increase in the number of Islamic Commercial Banks, the number of Sharia Business Units, and the number of BPRS which is quite encouraging.

However, this development cannot be

${ }^{24}$ Suad Firkiawan, "Manajemen Kompetensi Sumber Daya Manusia Bank Syariah Berbasis Prinsip-Prinsip Syariah Menuju Qualified Asean Bank," Al-Mashrafiyah: Jurnal Ekonomi, Keuangan, Dan Perbankan Syariah, 2018, https://doi.org/10.24252/al-mashrafiyah.v1i2.4734. separated from the support of various parties. The role of the government as a policy maker has provided many opportunities for the development of Islamic banks. Likewise, the increasing number of Islamic banking in Indonesia is certainly inseparable from the high public demand for Islamic banking services. This shows that the hard efforts of all stakeholders in the Islamic finance industry are needed to support the development of Islamic banks in Indonesia.

It is necessary to integrate movements and steps from the government, practitioners, academics and associations so that the development of Islamic banking becomes more effective. For this reason, the role of all parties, including the government, ulama, IAEI, academics, and the community in pioneering and encouraging integrated steps to answer these challenges is indispensable so that the national Islamic finance industry is of higher quality, develops sustainably and is able to compete in the global competition arena.

\section{References}

Afrelian, Muhamad Ibnu, Imahda Khoiri Furqon. "Legalitas Dan Otoritas Fatwa Dewan Syariah Nasional Majelis Ulama Indonesia Dalam Operasional Lembaga Keuangan Syariah", Jurnal Ilmiah Mizani, Vol. 6, No.1, 2019. http://dx.doi.org/10.29300/mzn.v6i1.2195

Andiko, Toha. "Signifikansi Implementasi Konsep Ekonomi Islam Dalam Transaksi Bisnis Di Era Modern”, Jurnal Ilmiah Mizani, Vol. 4, No.1, 2017. http://dx.doi.org/10.29300/ mzn.v4i 1.1004

Arabî, Ibn al-. Abkâm Al-Qurân, Juz 1. Mesir: Isa al-Halaby, 1957.

Alamsyah, Halim. "Perkembangan Dan Prospek Perbankan Syariah Indonesia: Tantangan Dalam Menyongsong MEA 2015.” Milad Ke-8 Ikatan Ahli Ekonomi Islam (IAEI), 2012.

Baqi, Muhammad Fuad Abd al-. Al-Mujam Al-Mufahras Li Al-Fazh Alquran Al-Karim. alQahirah: Dar al-Hadis, 2007. 
Faidlullah. Fath Al-Rahmân Li Thâlib Âyât AlQur'an. Semarang: CV. Diponegoro, n.d.

Fatah, Rohadi Abdul. Analisis Fatwa Keagamaan Dalam Fiqih Islam. Jakarta: Bumi aksara, 2006.

Firdaus, Rahmat. "Perbedaan Pandangan Fuqaha Ihwal Bunga Bank Dan Riba." Ekonomika Syariah: Journal of Economic Studies, 2019. https://doi.org/10.30983/es.v3i2.2150.

Hallaq, Wael B. "From Fatwâs to Furü: Growth and Change in Islamic Substantive Law." Islamic Law and Society, 1994. https://doi. org/10.1163/156851994X00147.

Hamid, Edy Suandi. "Akar Krisis Ekonomi Global Dan Dampaknya Terhadap Indonesia." La_ Riba, 2009. https://doi.org/10.20885/lariba. vol3.iss2.art1.

Haron, Sudin. Islamic Banking: Rules and Regulations. Petaling Jaya: Pelanduk Publications, 1997.

Haryono, Haryono, and Raudya Pertiwi. "Regulasi Lembaga-Lembaga Fasilitator Sebagai Penentu Arah Kebijakan Operasional Bank Syariah." Ad-Deenar: Jurnal Ekonomi Dan Bisnis Islam, 2020. https://doi.org/10.30868/ ad.v4i01.753.

Iqbal, Zamir, and Abbas Mirakhor. "Progress and Challenges of Islamic Banking." Thunderbird International Business Review, 1999. https:// doi.org/10.1002/tie.4270410406.

Jami’an, Rizal Bin. “Ijtihad Jama’i Nahdatul Ulama (NU) Dan Ijtihad Qiyasi Muhammadiyah Tentang Bunga Bank Dalam Praktik Perbankan." Jurnal Hukum Respublica, 2018. https://doi.org/10.31849/respublica. v16i1.1424.

Jashshash al-. Ahkam Al-Qur'an, Juz II. Beirut: Dâr al-Kutub al-'Ilmiyyah, n.d.

KBBI. "Kamus Besar Bahasa Indonesia (KBBI) Kamus Versi Online/Daring." Kemendikbud, 2020.

Mudzhar, M. Atho. "Revitalisasi Maqasid AlShariah Dalam Pengembangan Ekonomi Syariah Di Indonesia (Studi Kasus Atas FatwaFatwa DSN-MUI Tahun 2000-2006).” Jurnal Indo-Islamika, 2014. https://doi.org/10.15408/ idi.v4i1.1558.
Nawawi, Imam.Al-Majmu Syarh Al-Muhadzadzah. Tt: Dar al-Fikr, n.d.

Nofinawati, Nofinawati. "Perkembangan Perbankan Syariah Di Indonesia." JURIS (Jurnal Ilmiah Syariah), 2016. https://doi. org/10.31958/juris.v14i2.305.

Nur Rianto Al Arif, M., Ismawati Haribowo, and Ade Suherlan. "Spin-off Policy and Efficiency in the Indonesian Islamic Banking Industry." Banks and Bank Systems, 2018. https://doi. org/10.21511/bbs.13(1).2018.01.

Qardhawi, Yusuf. Fatwa Antara Ketelitian Dan Kecerobohan. Jakarta: Gema Insani Press, 1997.

Qardhawi, Yusuf. "Halal Dan Haram Dalam Islam.” Pustaka Nasional Pte Ltd, 2001.

Riadi, M Erfan. "Kedudukan Fatwa Ditinjau Dari Hukum Islam Dan Hukum Positif (Analisis Yuridis Normatif)." Ulumuddin, 2010.

Shihab, M. Quraish. Wawasan Al-Qur'an; Tafsir Maudhu'i Atas Berbagai Persoalan Umat. Bandung: Penerbit Mizan, 1998.

Singodimedjo. R.H. Kasman, Bunga Itu Bukan Bank Dan Bank Itu Tidak Haram. Jakarta: Pustaka Antara, 1972.

Suad, Firkiawan. "Manajemen Kompetensi Sumber Daya Manusia Bank Syariah Berbasis Prinsip-Prinsip Syariah Menuju Qualified Asean Bank." Al-Mashrafiyah : JurnalEkonomi, Keuangan, Dan Perbankan Syariah, 2018. https://doi.org/10.24252/al-mashrafiyah. v1i2.4734.

Syaukani, Muhammad Ali bin Muhammad al-. Fath Al-Qadîr Bayna Fann Al-Riwâyah Wa Al-Dirâyah Min 'Ilm Al-Tafsîr, Juz 1. Beirut: Dâr al-Fikr, n.d.

Wehr, Hans. A Dictionary of Modern Written Arabic. London: George Allen and Unwin Ltd, 1971. 